\title{
Where Had All the Flowers Gone? The Missing Space of Female Sonneteers in Seventeenth-Century England
}

\author{
DIANA E. HENDERSON \\ Massachusetts Institute of Technology
}

Les petits lieux de la poésie lyrique - et en particulier le sonnet - offraient un espace dans lequel les femmes du XVI siècle se sont retrouvées. Mais ensuite, qu'estil advenu en Angleterre de l'immense potentiel du sonnet féminin, en particulier après le premier quart du XVII siècle? Les chercheurs ont mis l'emphase sur les changements formels et de genre (essor de l'épigramme, l'hégémonie du couplet), et ont affirmé que le sonnet a décliné pour des raisons culturelles et artistiques (guerre civile, ombres de Shakespeare et de Milton). Toutefois, la poésie des XVII et XVIII siècles présente un défi aux récits de l'histoire de la littérature et à la présomption que les femmes ont perçu le pétrarquisme comme un territoire masculin. Au contraire, cette époque est celle où les femmes ont adapté les formes et les résonances du sonnet aux nouvelles réalités sociopolitiques, et avancé des revendications autoriales par la même occasion. Plusieurs de ces sonnets ont été mis de côté en raison de leur caractère paratextuel, ou viennent à peine dêtre découverts grâce à des études de manuscrits récentes. Ces sonnets mettent en lumière néanmoins la conscience artistique de ces auteurs féminines, et comment le récit d'histoire peut obscurcir la poésie que l'on considère. Il est donc temps de revoir nos présomptions au sujet $d u$ sonnet anglais et de remettre en question les constructions $d u$ romantisme et de la dominance shakespearienne, afin de redécouvrir l'héritage du sonnet du XVII siècle.

s the past quarter century of feminist scholarship has made obvious, six-
teenth-century European women found ample lodging in their stanzas,
From Veronica Gambara and Vittoria Colonna in Italy to Louise Labé, Anne
Lok, and Christian Lindsay in France, England, and Scotland respectively, 
female-authored sonnets were not only composed but widely circulated across time and place, in the newer forms of print publication as well as in manuscript and through transcriptions. Famously, Tudor Englishmen took up the sonnet as a potent space for narrative and dramatic manipulation as well as lyric expression, in contexts both political and erotic. Despite challenges and less visibility, by the first decades of the seventeenth century so too did Englishwomen acknowledge and cite both male and female forerunners in their use of interlocking rhymes, iambic pentameter couplets, and even, in Lady Mary Wroth's now canonized Pamphilia to Amphilanthus (published in 1621 as part of The Countesse of Montgomeries Urania), the sustained demands of a sonnet sequence at once tightly lyrical and ambitiously expansive. Keeping time in a metrical sense while balancing the temporal tensions among past tradition, the privileged moment and forward motion, the sonnet sequence - or, better put, the sonnet cycle - attests to both fluidity and mastery, within and beyond the present time. ${ }^{1}$ Among gathered leaves (to draw on but one common metaphor rooted in both Petrarchan tradition and material reality), an illusion of sustained poetic voice emerged as simultaneously natural and sophisticated. Moreover, the spatial expansion of lyric from a "trifle" or single "flower" within a miscellany into a sustained authorial assertion involving many "rooms" allowed Wroth and others to demonstrate narrative range and continuity, emblematizing female constancy through repeated patterns and images while achieving amplitude using rhetorical topoi, the "places" of poetic inventio. These female sonneteers were attempting to construct from stanzas their own palaces of art.

But what happened to female sonneteering after Wroth? The conventional answer is that the sonnet was exhausted, Wroth's achievement the last gasp of the Sidney circle's aristocratic assertion of an Elizabethan fad. The harsh reception of Urania as roman à clef served as a further reminder, if one were needed, that women published at their peril. Natasha Distiller emphasizes the importance of gender here, complicating Christopher Warley's emphasis on aristocratic conservatism as the determinant in reading Wroth; nonetheless, both scholars (like Rosalind Smith) place Wroth at the end of a tradition, and indeed Distiller concludes that as a consequence of Urania's reception there were no femaleauthored sonnet sequences between Wroth's and Mary Robinson's 1796 Sappho and Phaon. ${ }^{2}$

Slippage between gendered and form-based explanation increases when it is further asserted, as literary surveys generally do, that the imaginative space 
conjured within the sonnet shifted as the imagined addressee turned, in Donne and Herbert, from women to God. This claim does less to explain the dearth of female sonneteers than to reify those male poets' means of making the form their own, anew. It does not explain why literate women, whom we know read and valued Donne's and Herbert's poetry (which itself had been influenced by women poets including Mary Sidney), did not imitate those poets' redeployment of the sonnet as a space of religious self-abjection: this was, after all, a time when women produced ever-larger amounts of godly verse (and abjection, to recall Julia Kristeva, goes with the feminine territory).

Without addressing this oddity directly, Nigel Smith suggests a politically rooted explanation for mid-century poetic changes. Building on the work of those who claim that the impulses of sonnet and epigram coalesced in the early Stuart years to the latter's advantage, he asserts that "the sonnet absorbed the Civil War." By this he seems to mean that poetry formally mimicked political factionalization, producing what he calls the "fissiparation" of the sonnet into smaller units. ${ }^{3}$ Of the civil war years, Smith opines that whereas earlier "women had appropriated the male voice of the love lyricist in order to perform a critique of Petrarchan love conventions" (a common oversimplification to which I shall return), "the female lyric in the Interregnum possesses exactly the same voice as the male lover and poet, although often to different ends."

Certainly the couplet and epigram, already familiar in Tudor poetry, gained ground, and women's lyrics ranged more widely in the space they claimed on paper. The exhaustion-and-fissiparation-of-the-form theory cannot explain, however, why Milton chose to write savage indictments and urgent political protests - as well as a beautiful spousal hymn - in precisely the Petrarchan sonnet form, during the 1640s and 1650s. Nor do any of the usual theories account for the inclusion of a sonnet explicitly citing Petrarch's address to "Madonna Laura" in a 1687 lyric collection by Englishman Philip Ayres: this volume published at the century's close was popular enough to prompt four reprinted editions. ${ }^{5}$ The $100+$ sonnet sequence might admittedly be a thing of the past, but the sonnet form's space of authorial assertion was not - at least, not entirely. And thus, where are the women?

This question became more pressing for me when composing the essay on gender and subjectivity for the Cambridge Companion to the Sonnet, as I reviewed the seventeenth-century female absence in the wider context of a tradition that still plays a formative role in epitomizing literary history. I was 
struck by the inadequacies of the usual accounts when considering the range of possibilities later found in sonnets both collected and sequential, from the time of Anna Seward and Charlotte Smith through Elizabeth Barrett Browning and Christina Rossetti to Edna St. Vincent Millay and Julia Alvarez. ${ }^{6}$ Why, in an earlier age when female poets were generally deprived of a classical education, when literacies were variable but the sonnet's rhymes and rhythms available in a wide range of heard, spoken, handwritten, and printed forms, did women not avail themselves of a poetic space that was ready to hand?

Such questions led me to recontextualize what I did know, in light of recent work on women's communities, literacies, and compositional practices as well as the resurgence of interest in historical aesthetics. ${ }^{7}$ What I learned made me increasingly uncomfortable with the old story, or even the more recent account derived from the path-breaking, often exquisite work of John Freccero and Nancy Vickers which has nonetheless led to an almost automatic presumption that the Petrarchan model of lyric was a deeply insular, masculinist, and aggressive space, be it in its self-involved subjectivity, its blazoning of female beauty as a compensatory strategy of mastery, or its narrow characterization of the woman's part. ${ }^{8}$ This once-powerful corrective to formalist appreciation and reverence for an all-male canon has come to carry similarly dismissive force for those interested in female sonneteers. It has become, if you will, a "mistress narrative" that precludes further exploration of the potential variety and possibilities of sonnets, which might otherwise be included and indeed uncovered within the archival projects of this generation's readers of women's writing.

While we have tried to supplement that gendered critique of Elizabethan Petrarchanism, ${ }^{9}$ I could not find comparable challenges, or even an address of the question of the missing female sonneteer, in studies focused on the Caroline and Commonwealth era. What I did find was that the revision of traditional categorizations delimited by nation and genre, which historicist study of women's writing has encouraged, provides even more reason to cast a skeptical eye upon our inherited account of the sonnet's seventeenth-century fate.

For example, several essays in the 2005 volume Strong Voices, Weak History, edited by Pamela Benson and Victoria Kirkham, make clear that female sonneteers of the Italian cinquecento were not only published in both all-female and mixed sex anthologies but were also venerated in England by, among others, John Harington and Thomas Heywood. Virginia Cox emphasizes the "memory chains" across generations of women's writing, with Vittoria Colonna's version 
of Petrarchismo having canonized her "for a feminine literary posterity that flourished well beyond Italy." ${ }^{10}$ Her praise of conjugal love adapted the sonnet to what should have been a more broadly acceptable model for English helpmeets as well; the Bodleian Library's first printed catalog of 1605 certainly contained Colonna's work. Pamela Benson argues that Mary Wroth's figuration of her aunt as the "queen of Naples" in Urania may indeed have strengthened the connection between Lady Mary Sidney Herbert and Colonna (Napoli being the area in which Colonna lived as marchesa of Pescara). ${ }^{11}$ This particular instance and its consequent association of various dimensions of Petrarchism - notably Mary Sidney's translation of the Trionfo della morte with its interview of the beloved Laura, and Colonna's sonnets - suggest that a female Petrarchan tradition could transcend specific genres as well as rise above the general "stigma of Italy" for the English, crossing boundaries of time and space in the process. ${ }^{12}$ And indeed, three years later in 1624, Thomas Heywood cited Vittoria Colonna as a paragon to strengthen by association his praise of female English poets, including Mary Sidney Herbert.

Let us go a step further. The Tuscan "Sappho" Laura Battiferra dedicated her 1560 Petrarchan anthology to a Medici duchess, having earlier dedicated a pair of sonnets to Philip II and Mary Tudor. ${ }^{13}$ For a Catholic Englishwoman such as Elizabeth Tanfield Cary, one may speculate whether that Italian precedent provided a direct model; what is undeniable is that Cary in 1630 wrote a formal sonnet of dedication to Queen Henrietta Maria. ${ }^{14}$ In fact, Cary added it by hand to The Reply of the Most Illustrious Cardinall of Perron, her printed translation which had been published in Douay - the result being another female-authored Catholic import to England, addressed to another Medici princess:

1. To the Queenes most Excellent Majestie

'Tis not youre faire out-side (though famous Greece

Whose beauties ruin'd kingdoms never sawe

A face that could like yours affections drawe)

Fittes you for the protection of this peice

It is your heart (your pious zealous heart)

That by attractive force, brings great Perroone

To leave his Seyne, his Loyre, and his Garroone;

And to your handmaide Thames his guiftes imparte: 
But staie: you have a brother, his kinge borne,

(Whose worth drawes men from the remotest partes,

To offer up themselves to his desartes.)

To whom he hath his due allegiance sworne

Yet for your sake he proves ubiquitarie

And comes to England, though in France he tarrie. ${ }^{15}$

Although a dedicatory sonnet, the octet sits squarely within the Petrarchan tradition of amatory rhetoric shared by Sidney and Spenser: the first quatrain establishes the addressee's "faire out-side" but then the second prioritizes her pious heart (albeit, unlike Stella's or Elizabeth Boyle's Virtue, the piety here is of a Catholic variety). The volta at line 9 conventionally complicates the narrative direction, the ejaculatory "staie" also noting that the figure being translated - literally carried across - also "stays" in France, requiring another twist and the almost obligatory paradox (here, of double location) in the final couplet. And indeed, the initial $a b b a$ rhyme scheme as well as the slant rhymes of the third quatrain allow one to hear echoes of the tighter Italian form, before the couplet finally brings the poem "home" to England. Even as fluid metonymies (and water transport) allow "Perroone" (as text) to leave "Garroone" for Thames, then, the man and the female-authored sonnet defy easy placement, or rather (like Carey's idealized image of royalty and Catholicism's very name) link nations, poetic traditions, genders, and artistic forms in a "ubiquitarie" space.

In precisely the same year that Cary penned her poem, John Milton similarly composed a dedicatory sonnet that, two years later, would become his first poem to appear in print: "On Shakespear" ("What needs my Shakespeare for his honour'd Bones...") was young John's contribution to the 1632 Second Folio. His invocation of the earlier poet as still vital ("Thou in our wonder and astonishment/Hast built thyself a live-long Monument") furnishes a temporally grounded invitation to reconsider Cary's poem against the background of the 1609 Sonnets. Whether a direct influence or not, Shakespeare's sonnet no. 53 ("What is your substance, whereof are you made / That millions of strange shadows on you tend?") provides a model for several of Cary's strategies.

In each poem, the invocation of classical models serves to "shadow" the modern fulfillment of beauty within the heart, providing a parallel occasion for the poet him/herself to "outdo" prior praise-givers in having the unique "heart" 
of the beloved as poetic subject. The singularity of the admired addressee nevertheless evokes paradoxical multiplicity and comparison. But Shakespeare's lines resonate with far more ambiguity, moving from the seeming forthrightness of its bold initial question to a final line that may or may not mark a volta, may or may not encourage us to wonder whether "like none, none you" simply extends the overt praise or raises a "shadow" of uncertainty about the beloved's constancy. What becomes clearer by contrast is how Cary's female addressee is forced into competition with another "attractive force," her royal brother; thus the transcending figure is actually the text itself, the "great Perroone" who "proves ubiquitarie" only because of Cary's own act of translation. She thereby overcomes the competing claims of contending kingdoms (and gendered sibling rivalry) through a cross-gendered performance of authorial collaboration. The differences here befit the poems' audiences and occasions - or rather, in the instance where we can pin down said occasion, Cary's relative clarity about the terms of praise (the heart's religiosity) and her necessary authorial boldness make sense, whereas the ambiguity of Shakespeare's matches the shadowy narrative and shifts in "character" within his collected sonnets.

At least into the 1630s, then, the sonnet continues to draw on familiar rhetorical and sonic strategies, but is also being used within a different gendered context to create an artistic space that expresses something other than carnal desire. Milton's better-known use of the dedicatory sonnet to locate himself within a poetic genealogy and community (discussed by Douglas Lanier among others) in fact resonates not only with Cary's contemporary effort to participate in print as well as manuscript culture but also with a number of women's invocations of earlier writers. The sonnet possesses currency as a form of personal tribute both to and from women, at times suggesting a more benign space of imagined community than emergent nation-states could then conjure. The range of female authors and addressees - from Elizabeth Melville, Lady Culross among the Scottish dissenters, ${ }^{16}$ to Mary Wroth and Lucy Countess of Bedford among the Pembroke Protestants, to Catholic Elizabeth Cary addressing the Catholic queen - transcends the bitter factionalization that was driving the Continental wars and which would rive the British Isles in the coming decades.

And even then, the transnational invocation of Petrarch persisted: in 1644, Anna Hume published her translation of three of his Trionfi, thereby participating in a reformed Scots alliance with European tradition - while 
explicitly (and perhaps implausibly) denying that she had read English translations, even those by Queen Elizabeth and Mary Sidney. Kate Chedgzoy observes that, given the late date of this work compared with continental women writers' Petrarchismo, Hume's "Petrarchanism may... be read as a gendered site of literary memory, inscribing an earlier moment of European women's cultural participation as a force that could continue to facilitate female creativity." ${ }^{17}$ At the same time, it is hard to ignore the blatant defiance of southern English dominance here (female as well as male), and also the political topicality implicit in doing so. Hume apparently wrote other verse for circulation, including writings she said had pleased Elizabeth of Bohemia, but they do not survive: publishing the Trionfi, she assured her textual space in the Petrarchan tradition, albeit not in sonnet form.

Which returns us to the question of the form per se, of what counts as a sonnet on the space of the page. In the same year that Cary inscribed her dedicatory sonnet to Henrietta Maria, Diana Primrose published A Chaine of Pearls, or a Memoriall of Q. Elizabeth. This volume included a sixteen-line dedicatory poem by Dorothy Berry and then a 24 -line Induction by Primrose:

As Golden Phoebus with his radiant face

Enthron'd in his Triumphant Chaire of State,

The twinkling Stars and Asterismes doth chase

With his Imperiall Scepter, and doth hate

All Consorts in his Starry Monarchy,

As prejudiciall to his Soveraignty.

So Great Eliza, Englands brightest Sun,

The Worlds Renowne and everlasting Lampe,

Admits not here the least Comparison;

Whose Glories, doe the Greatest Princes dampe.

That ever Scepter swaid or Crowne did weare,

Within the Verge of either Hemispheare.

Thou English Goddesse, Empresse of our Sex,

O Thou whose Name still raignes in all our hearts,

To whom are due, our ever-vowd Respects!

How shall I blazon thy most Royall parts?

Which in all Parts did so divinely shine,

As they deserve Apollo's Quill (not mine.) 
Yet, since the Gods accept the humble Vowes

Of Mortalls; daigne (O Thou Star-crowned Queene)

T'accept these ill-composed Pearly-Rowes:

Wherein, thy Glory chiefly shall be seene:

For by these Lines so black and impolite,

Thy Swan-like Lustre shall appeare more white:

Thy Emperiall Majesties eternall Votary, Diana. ${ }^{18}$

Viewed thus on the page, the Induction does not encourage us immediately to think "sonnet," yet its reading reveals Petrarchan kinship. This poem appears prior to the lyric sequence itself, which is written in couplets retrospectively blazoning the dead queen's virtues; as Lisa Gim points out, the Chaine excludes physical beauty in favour of attributes such as Prudence, Science, and Fortitude (seldom associated with femininity). ${ }^{19}$ Here, within the ababcc stanza form, Primrose likewise invokes the blazon tradition in order to reject its possibilities, and in the best Petrarchan tradition relies on wit and oxymoronic structures to assert the impossibility of comparison even as the poetry does just that (from the initial "As Golden Phoebus... So Great Eliza" to its concluding foil for her "Swan-like Lustre"). The combination of prefatory verses and the "pearls" again demonstrates that Caroline women could both manipulate the component parts of the sonnet form and conjure Petrarchan tropes such as the blazon, but to their own ends and, here, not in what we now have standardized as the English or Shakespearean sonnet form.

Such difference-in-resemblance challenges the fit between their poetic choices and our categorizations. This is not altogether surprising. For of course we know, but too seldom register, that the books entitled Songs and Sonnets or Eclogues, Epitaphs, and Sonnets had, from the time of Tottel and Barnabe Googe onward, included a variety of poems that only sometimes matched the fourteen-line form derived from Wyatt and Surrey (who themselves produced couplet verse and other lyric forms). Indeed, many of Thomas Watson's poems in Hekatompathia, which was regarded as the first English sonnet sequence until Anne Lok's penitential sonnets were rediscovered, are eighteen lines long. And when Greensleeves was a "new tune," the lyrics now classified as a "broadside ballad" were advertised as "A new courtly sonnet, of the Lady Greensleeves." ${ }^{20}$ Nor did the subsequent printed "sonnet craze" of the 1590s displace this wider 
sense of the sonnet as a little song, or elevate and disconnect it from other short lyric forms. The poems explicitly called "sonnets" in Lady Anne Southwell's 1626 manuscript include some couplet poems and some with interlocking rhyme, some with line length alternating between pentameter or tetrameter and dimeter, some made up of fourteen lines and some not. ${ }^{21}$ Among them is the following:

Fayne would I dye whilst thy braue muse doth liue,

Quaintest of all the Heliconian traine

Rays'd by thy arte-full quill, that liues doth give

Unto the Dullest things, thy fiery straine

Adds Immortalitye, maugre priuation

And by thy power brings forth a new Creation.

Unhappy they that poesye professe

Rayseinge their thoughts by any starr but thyne

Not lett them thinke coelestiall powers will blesse

Loose ballads or Hyperbolizeinge Ryme

Curst bee those sulphrous channels that make stincke

Each christall dropp $y^{t}$ in theyr cranyes sincke

In throne thy phoenix in Hi Jehouahs brest

Since shee aproues hir selfe bird of that nest

Soe shall she liue immaculate and blest. ${ }^{22}$

Louise Schleiner dubs this fifteen-line poem a "quasi-sonnet," and for us this seems apt, in that it reverses what Phillis Levin regards as Petrarch's fundamentally "top-heavy" eight-and-six organization while mixing interlocking quatrains and couplets before the final triplet. ${ }^{23}$ Then again, Petrarch himself varied his length and form in the Canzoniere, and Sir Philip Sidney's influential sonnet sequence includes other song forms, as does - with a difference - Wroth's. Conversely, Herbert's volume entitled The Temple: Sacred Poems and Private Ejaculations includes formal sonnets such as "Prayer" and "The Holdfast." The poet Southwell, whom Schleiner associates with "Donne, Herbert, Carew" as a "female 'metaphysical' poet," may also be playing with some acrostic meaning in the indented lines spelling the name "Quarles": she was part of a courtly circle that engaged in what Schleiner calls (literary) "parlor games." ${ }^{24}$ More explicitly, Southwell is eager to distinguish true poetry from "loose ballads," although her 
primary criterion of value is piously moral. Yet despite her professed disdain for hyperbole in rhyme, Southwell's vivid contrast between "sulphrous channels" and "each christal dropp" resembles Primrose's inky conclusion (and many another programmatic sonnet invoking Helicon alongside its oxymora). In other words, the subjectivity, tropes, and allusions of what the period regarded as part of the sonnet tradition do appear here, and help ground an alternative aesthetic to formalist elevations of line and rhyme alone.

Lucy Hutchinson, in her autobiographical fragment, confesses that "she was not averse to 'wittie songs and amorous sonnets or poems' in her youth" and in her Memoirs of the Life of Colonel Hutchinson even makes such writing a spur to her idealized marriage: "Listening to 'a lady's' song one night, [the Colonel], 'fancying something of rationality in the sonnet, beyond the customary reach of a she-wit" learns that she shuns men, but he perseveres as he "lov'd her soule and her honor more than her outside." ${ }^{25}$ This episode, stressing the female author's substantiality in lyric form as a gateway to connubial bliss, seems almost an exact inversion of the post-Vickers reading of how early modern sonnets functioned, in their emphases and attributes as well as in the gendering of authorship. Furthermore, song and sonnet here are used both sequentially and interchangeably, defying modern theorists such as Paul Oppenheimer who, in The Birth of the Modern Mind, ${ }^{26}$ builds on a Dantean distinction to argue that the sonetto was meant to be read rather than sung and that it explicitly encouraged our practice of silent reading. More fittingly, Heather Dubrow calls attention both to early modern poetic self-consciousness about the poem's physical appearance on paper and to the signs of alternative emphases challenging the fourteen-line column as the all-important spatialized unit: one of her examples, tellingly, comes from Mary Wroth's corona, which Dubrow claims is "virtually a single poem," a reading reinforced by Wroth's "scribal practice." ${ }^{27}$

Has the combination of the print revolution and the Romantic revival of Wordsworth and friends, then, led us to overemphasize the distinctiveness of their sonnet form belatedly, once it had become a classic, and as a result to miss the protean play and experimentation persisting in an era when such verse was, if not exactly new, not yet an unambiguously venerated pillar of the poetic establishment? In reviewing anthologies with this question in mind, I have become even more aware of the consequentiality of our answer for the presence or absence of female lyric poets, but also for our understanding of seventeenth-century aesthetics more broadly construed. 
It is no coincidence, I think, that Elizabeth Cary's sonnet cited earlier appears in Kissing the Rod (1988), a groundbreaking feminist anthology of women's verse which showed great editorial willingness not only to discover but to repackage writing in ways that would make its aesthetic resonance visible. Thus too that volume includes within its introduction a poem from the 1690s (honouring James Frances Edward Stuart, the "Old Pretender") described by the editors as a "sonnet," although it is made up of seven quite epigrammatic couplets:

\author{
"Lines on seeing King James's Picture" \\ What Briton can survey that heavenly face \\ And doubt his being of the Martyr's race? \\ His every feature doth his birth declare; \\ The monarch and the saint are shining there. \\ That face must sure the boldest Whig convince \\ Which speaks at once the Stuart and the prince. \\ O lovely Youth, 'tis evidently plain \\ By thy majectick look thou art born to reign. \\ My heart bleeds as I view this noble shade \\ And grieves it cannot bring thee better aid; \\ I on no other terms a man would be \\ But to defend thy glorious cause and thee. \\ $\mathrm{O}$ were my pen a sword that I in fight \\ Instead of verse might vindicate thy Right.
}

Here the combative turn and use of the couplet might just as aptly support Nigel Smith's reading of the sonnet's "fissiparation" as it does the continuation of a Renaissance tradition. And in fact, even this collection of lines turns out to be a conflated version drawn from three manuscripts, none of which is contemporary with its composition; ${ }^{28}$ the editorial choice to decide it was "probably" written in this form is justified as producing the "clearest and most concise" version. The result does indeed resemble a standard sonnet in the placement of its volta (shifting from praise to pathos and thwarted personal desire at line 9) and in the conventional self-consciousness about its versifying in the final couplet - though of course one must also wonder whether the logic here is circular, the formal sonnet's legacy in some measure determining 
what constitutes clarity and appropriate length. Such an aesthetic judgment is not necessarily anachronistic: after all, in A Short Treatise on Verse King James VI and I (an ancestor of this poem's subject) had endorsed the sonnet form for poems of praise, and "Samuel Daniel praised the sonnet as 'neither too long for the shortest project, nor too short for the longest."' ${ }^{29}$ Kissing the Rod's decision nevertheless serves as a reminder that later, after the development of a print public sphere, such views - both literal and figurative - took on far more weight and aesthetic self-evidence: the editors' particular textual choices signal the ongoing power of being "sonnet-like" as a means of encouraging scholars (especially non-feminist ones examining women's writing?) to take a short verse seriously, and thus to make a space for female lyric authorship.

Perhaps more surprisingly, the few seventeenth-century poems in recent transhistorical sonnet anthologies edited by contemporary poets (both male and female) include similar seven-couplet sonnets without special signals or discussion, despite the editors' introductory stress upon the importance of the volta as a turn in structure as well as argument, and despite contextual frames that emphasize the familiar story of the sonnet's seventeenth-century decline. For instance, in Edward Hirsch and Eavan Boland's The Making of a Sonnet, which prefaces "The Seventeenth Century" rather melodramatically ("But England was darkening....A mood of anti-Petrarchanism was in the air"), ${ }^{30}$ one encounters such couplet "sonnets" as Lord Herbert of Cherbury's "Epitaph of King James," Thomas Carew's tetrameter "Song: Mediocrity in Love Rejected," and Robert Herrick's civil war poem "The Bad Season Makes the Poet Sad." Significantly, the editors end the seventeenth-century section with Aphra Behn's "Epitaph on the Tombstone of a Child, the Last of Seven That Died Before," another "sonnet" all in couplets consequently allowing the inclusion of an important early modern female author.

Phillis Levin (like Boland, a female poet as well as anthologist) similarly includes Herrick's couplets in her sonnet anthology, as well as Herbert's verses sent to his mother printed (with requisite white space) as a double sonnet, John Donne's eighteen-line poem entitled "Sonnet: A Token," and Milton's caudated sonnet "On the New Forcers of Conscience," a Commonwealth protest poem with its six-line coda including two half-lines. Such instances could be multiplied - and could be further supplemented. Considering the widespread experimentation with spatial form, the printed page, and the "freeing" of verse from many kinds of perceived constraint during the twentieth century, it may 
after all be quite logical that it should be poets themselves who are comfortable with a broader definition of the sonnet now - with beneficial results for our historical understanding of aesthetics, even if the insights did not originate from historicist scholarship. Indeed, they might spur a reconsideration of the accuracy of that scholarship, at least as it has simplified the shapes and rhymes we consider in defining this poetic form.

After all, from the very start the couplet has been a hallmark of the English sonnet - and not only at its formal conclusion. In the interlocking rhyme scheme of the Spenserian sonnet, for instance, the tension between couplets and larger groupings such as the quatrain, octave, and sestet allows more variable placement of pauses and turns without marring the formal coherence of the space in which these elements are conjoined (as well as providing echoes of older forms such as rhyme royal, and the poet's own epic stanza). At the other end of the metrical spectrum, the critical tendency to fault a jarring turn in the final couplets of Sidney and Shakespeare may, after all, say more about our anachronistic back-formation than about a flaw in their poetic craft or conception of the way the sonnet's pieces should fit together. Considering the couplet's nearly hegemonic dominance in seventeenth-century lyric, then, it should not be so surprising to find there renewed emphasis on its possibilities in the form of the sonnet as well, building upon the Tudor foundation of a (predominantly) fourteen-line space within which subdivisions and shifts signify variably.

The basic point is this: given such variations today within anthologies compiled by well-respected poets conscious of and devoted to the sonnet form, and given the undeniable truth that the sonnet continues to serve as a fundamental building block in poetic education, it seems especially timely to consider possible, historically grounded variations on the sonnet theme that might make women's writing of the early modern era more visible as part of the now-classical legacy.

In addition to the Behn couplets and the Primrose prefatory poems noted above, for example, we might add a piece by the most famous female poet of the age, the "Matchless Orinda." In fact, Katherine Philips's first print publication was a fourteen-line iambic pentameter poem. In a presentation copy of her manuscript, it reads:

\section{In Memory of Mr Cartwright}

Stay, Prince of Phancie, stay, we are not fit 
To welcome, or admire thy Raptures yet;

Such horrid Ignorance benights the Times,

That Wit \& Honour are become our Crimes.

But when those happy Pow'rs which guard thy dust,

To us, \& to thy Memory shall be just,

And by a flame from thy blest Genius lent,

Rescue us from our dull Imprisonment,

Unsequester our Fancies, \& create

A Worth that may upon thy Glories wait:

We then shall understand thee, \& descry

The splendour of restored Poetry.

Till when let no bold hand profane thy shrine,

'Tis high wit-Treason to debase thy coin. ${ }^{31}$

The poem directly addresses the royalist poet and playwright William Cartwright, who died of camp fever at Oxford in 1643; as Millman and Wright observe, Philips (born 1631/32) "could not have known him personally."32 The poem appeared in print in 1651, as one among 54 commendatory verses introducing a posthumous collection of Cartwright's Comedies, Tragi-Comedies, With other Poems. What at first might appear yet another dedicatory tribute fascinates when recontextualized: here is the twenty-year-old royalist Philips, recently married to a Commonwealth sympathizer, lamenting the "horrid Ignorance" that "benights the Times" in part by forbidding the public performance of plays such as Cartwright's. Whereas the first quatrain refuses to let go of the pre-war past and Cartwright, the next eight lines imagine a future when "a flame from thy blest Genius" shall "Rescue us from our dull Imprisonment" and reveal "The splendour of restored Poetry." The coincidence of poetic and royalist political rhetoric could not be more exact, culminating in the last couplet's turn to the present time, in which it is "wit-Treason" to "debase thy coin" or disturb the "shrine" of the dead "Prince." Nor could the formal play between a unifying conceit and the use of quatrain and final couplet to mark temporal turns be more sonnet-like. Post-romantic notions of lyric authenticity residing in direct personal relations may blind us to the artistry here, just as rhyme scheme may have led us to miss the way dedicatory praise poems may participate meaningfully in the sonnet tradition. At a time of particular importance in the emergence of political print culture and a concomitant "public sphere" (however complex that 
term's historical location has become), Philips's poem adds to the substantial body of verse indicating that the sonnet remains vital in the seventeenth century, both as a space of literary community building (whether personal or, as here, impersonal) and as a verbal structure bridging gaps (poetic, temporal, personal, political) through paradox and rhetoric.

As we explore manuscript archives as well as print, we might attend to a substantial number of 14- and 28-line poems by women, some of which also play with the structural turn and tropes such as the blazon, and may even be consciously echoing the double sonnet structure after the model of, say, those George Herbert poems to his mother Magdalen (herself famously the friend of John Donne). ${ }^{33}$ Consider three 28-line poems by the unknown "Ephelia": one addressed to "Maidenhead," one including a mock blazon of the beloved, and a third dedicated to Aphra Behn. Taken together and respectively, these poems carry on the legacy of the sonnet as an appropriate form for erotic play, enduring love, and epideictic salute. ${ }^{34}$ Tonally distant from "Ephelia" but not, perhaps, so far from John Donne's remarkable combination of morbid self-dramatization, wit, and deep emotion is Anne Bradstreet's 28-line "Before the Birth of one of her Children," which shifts from meditation to legacy poem after line fourteen.

Among those adhering to the rule of fourteen, one might note several of the couplet "Poems of the Honourable Mrs. Henry Themilby," as they were published by Arthur Clifford in his 1813 edition of Tixall Poetry: Gertrude Aston Thimelby's many lyrics include "Upon the Returne from our Friends in Stafordshire," "To my Brother and Sister Aston, on their Wedding-Day, Being Absent," and a poem to Sleep, invoking a common sonnet topic (with classical roots reaching back to Statius) and adhering to the logical and syntactic shape of an English sonnet. ${ }^{35}$ And then there is the knotty logic of Hester Pulter's "The Circle," included in her manuscript Poems Breathed forth by the Nobel Hadassas [i.e., Esther]:

Those that the hidden Chimick Art profess

And vizet Nature in her Morning dress

To Mercurie and sulpher filterys give

That they consum'd with Love may live

In their Posterytie and in them shine

Though they their being unto them resign

Glorying to shine in Silver and Gold 
Which Fretting vermill poison doth infold

Forgetting quite that they were once refin'd

By time and Fate to dust are all Calcind

Lying obliviated in their Urn

Till they to their great Ancesters return

Soe Man the Universe's chiefest Glory

His primitive's Dust (Alas) doth end his story. ${ }^{36}$

Pulter's intellectual "refinement" and godliness may first recall Donne, although her biography connects her with that other giant of sonnets and theology, John Milton: his Sonnet X, "To the Lady Margaret Ley," is addressed to Hester's sister. But we are now far from the Jacobean courtly networks in which Donne honoured Lucy, Countess of Bedford and Ben Jonson saluted Mary Wroth (using her sonnet form as a component gesture of his praise); personal networks during the civil war years are notoriously difficult to decipher. Here, blood certainly does not signal proximity or other forms of alliance: Hester and Arthur Pulter were far removed, physically and politically, from Milton and Margaret. Nevertheless, the literary lines remain suggestive of shared readings and traditions, ones that include women across the political spectrum. And thus, while we try to decode these distant meanings, we might also even think again about two fortuitous instances in which an acrostic poem of the 1650s creates a fourteen-line variation on the sonnet theme, one by Elizabeth Major on her own name in Honey on the Rod $d^{37}$ and one by Elianour Havey upon the death of Oliver Cromwell, using his. ${ }^{38}$ Certainly here is wit and awareness of form that can be invoked paradoxically: either to emphasize that the poet rejected the strict rhyme scheme of the English or Petrarchan sonnet as we know them (by now I hope an unsatisfyingly superficial conclusion), or to reveal a kinship in length, meter, and function.

In 1930, Louis Zukovsky wrote "It is time someone resurrected the sonnet from a form that has become an exercise"; citing him in 2008, editor Jeff Hilson argues that "What is needed is a radical defamiliarisation of the form. If the linguistically innovative sonnet can be said to have a 'story' it is precisely this...." ${ }^{39}$ Attention to the consciously literary tradition that the space of the sonnet encapsulates has not been at the top of the scholarly agenda either for feminist archival scholars or most literary critics working in the early modern period recently. Their reasons may have been and may be good, but in the 
service of both a richer historical understanding of poetry and present-tense feminism, we do need to think more creatively about form and descriptive (rather than prescriptive) aesthetics as part of our archival and theoretical projects. We should take into account the more recent works on lyric and gender that stress the need to read multiply and look in unexpected places: not only scholarship by those within the early modern field, such as Heather Dubrow (and allied work on literacies by Margaret Ferguson and localities by Kate Chedgzoy), but also those working beyond our period, such as Yopie Prins and Virginia Jackson. In doing so, we may also help begin to address what Hilson sees as the enduring problem in modernist attempts to apply notions of "apt use" to the sonnet: "The problem... is their refusal to submit the form to historical change." ${ }^{40}$ My intention here is not to enshrine a new "mistressnarrative," and the results may not radically alter our overall understanding of seventeenth-century lyric changes. Nevertheless, by putting our knowledge of history, biography, and media into more productive dialogue with our formal literary perceptions, we might thereby allow more time and space in our current moment for attention to both the social and artistic consequentiality of poetic forms. Who knows what new insights might come of that?

In the meantime, if couplet sonnets are to be allowed in general anthologies, let's add a few more by women. ${ }^{41}$ I will conclude with two promising candidates that, among other things, remind us that the space of the sonnet was never that of a pure and separate aesthetic object, and thus those poems embedded in particularized locations and long-past social exchanges need not now be rejected on those spurious grounds. The first of these poems is by Anne King, sister of poet (and only latterly Bishop) Henry King; ${ }^{42}$ it originally accompanied a portrait she drew from memory and in memory of a friend, John Hales, soon after a Commonwealth crackdown dispersed her intimate circle.

\footnotetext{
“Under Mr. Hale’s Picture"

Though by a sodaine and unfeard surprise,

Thou lately taken wast from thy friends eies:

Even in that instant, when they had design'd

To keipe thee, by thy picture still in minde:

Least thou like others lost in deths dark night

Shouldst stealing hence vanish quite out of sight;

I did contend with greater zeale then Art,
} 
This shadow of my phancie to impart:

Which all shood pardon, when they understand

The lines were figur'd by a womans hand,

Who had noe copy to be guided by

But Hales imprinted on her memory.

Thus ill cut Brasses serve upon a grave,

Which less resemblance of the persons have. ${ }^{43}$

A second worthy candidate is the dedicatory poem by Delarivier Manley included in the 1696 edition of Catharine Trotter's Agnes de Castro, at a moment when these writers were still on good terms and composing for the stage:

To the Author of Agnes de Castro.

Orinda, and the Fair Astrea gone,

Not one was found to fill the Vacant Throne

Aspiring Man had quite regain'd the Sway,

Again had Taught us humbly to Obey;

Till you (Natures third start, in favour of our Kind)

With stronger Arms, their Empire have disjoyn'd,

And snatcht a Lawrel which they thought their Prize,

Thus Conqu'ror, with your Wit, as with your Eyes.

Fired by the bold Example, I would try

To turn our Sexes weaker Destiny.

O! How I long in the Poetick Race,

To loose the Reins, and give their Glory Chase;

For thus Encourag'd, and thus led by you,

Methinks we might more Crowns than theirs Subdue.

$$
\text { Dela Manley }{ }^{44}
$$

In each case, the poem, which for my argument's sake I will dub a sonnet, calls attention to the ways in which the poet's literacy is a social rather than solitary act, ${ }^{45}$ carrying layers of personal politics and the poignancy of time passing. In line 6 of Anne King's poem, the very word order set against meter forces special attention to the things that "vanish": for her, first under duress and then due to illness and death, Mr. Hale, and subsequently her cherished circle of friends forced to disband; for us, her accompanying portrait, which Isaak Walton 
praised but which is now (alas) lost, as are the poems she wrote in dialogue with her brother, of which only his remain. Manley's poem provides a cheering antidote to King's disparagement of her "woman's hand," using the volta at line 9 to shift from praise to identification and collective action. Lest we sentimentalize that turn, however, we must also recall both Manley's own fallings-out with her female rivals and the criticism to which she was subjected by influential men on the basis of this poem. But perhaps now we can try just a bit to redeem the lost time and imaginative space of these women's lyric productions. We can make a place for King's and Manley's words in our great traditions, however we decide to define them, or at least in our contemporary reading. "Thus Encouragd," let us look more expansively as well as locally when we quite rightly argue that women's writing should be included among the "endless monuments" of early modernity. Let us look to the sonnet.

\section{Notes}

1. Heather Dubrow reemphasizes the lyric distinctiveness that conspires against the linearity implicit in "sequence": "the presence of narrativity varies so much from one collection to another and often within a given collection that we should discard the 'sonnet sequence' in favor of 'sonnet cycle' when generalizing about the English tradition," in The Challenges of Orpheus: Lyric Poetry and Early Modern England (Baltimore: The Johns Hopkins University Press, 2008), p. 179. Recent work on the Folger Shakespeare Library's Wroth manuscript provides a case in point, as Dubrow, Ilona Bell and Gavin Alexander reveal less narrative linearity than the print publication has encouraged: see Alexander's “Constant Works: A Framework for Reading Mary Wroth," Sidney Journal 14.2 (1996-97), pp. 5-32 and Dubrow's “'And Thus Leave Off”: Reevaluating Mary Wroth's Folger Manuscript, V.a.104," Tulsa Studies in Women's Literature 22.2 (Autumn 2003), pp. 273-91. Perhaps, given my discussion here, we should return periodically to the common title "songs and sonnets" for a more historically grounded shorthand (and corrective) when discussing these early modern lyric collections - keeping in mind here too the variability among collections in their attentiveness to the relationship between the two terms and the sonic origins inhering in each word (in Italian, "sonetto" meaning "little sound," and sonnets beginning as little songs). 
Whereas Rosalind Smith emphasizes limitations and absence in her study of earlier Englishwomen's sonnets concluding with Wroth, I begin where she leaves off and build upon her more promising conclusion that both "gender and genre are contingent categories, simultaneously contained by the past and rewritten at each moment of their articulation and interpretation." See Smith, Sonnets and the English Woman Writer, 1560-1621, Early Modern Literature in History (Basingstoke: Palgrave Macmillan, 2005), p. 122.

2. Natasha Distiller, Desire and Gender in the Sonnet Tradition (Basingstoke: Palgrave Macmillan, 2008), p. 98; see also Christopher Warley, Sonnet Sequences and Social Distinction (Cambridge: Cambridge University Press, 2005).

3. Nigel Smith, Literature and Revolution in England, 1640-1660 (New Haven: Yale University Press, 1994), pp. 256, 259.

4. Nigel Smith's phrasing in the prior sentence appears unintentionally misleading: "Of course women had written lyrics, even sonnet sequences, before - Aemilia Lanyer [sic] being a prominent example" (p. 257). Recent work has challenged his generalization about men and women writing in "exactly the same voice": see among others Elizabeth Clarke, "Ejaculation or Virgin Birth? The Gendering of the Religious Lyric in the Interregnum," in "This Double Voice": Gendered Writing in Early Modern England, ed. Danielle Clarke and Elizabeth Clarke (New York: St. Martin's Press, 2000), pp. 208-29.

5. Cited from Edward Hirsch and Eavan Boland, eds., The Making of a Sonnet: A Norton Anthology (New York: W. W. Norton \& Company, 2008), where it is entitled "A Sonnet, of Petrarc, Shewing how long he had lov'd Madonna Laura." Ayres's Lyric Poems also includes a sonnet after Tasso (pp. 114, 401).

6. See Diana E. Henderson, "The Sonnet, Subjectivity, and Gender", in The Cambridge Companion to the Sonnet, ed. A. D. Cousins and Peter Howarth (Cambridge: Cambridge University Press, 2011), pp. 46-65.

7. On intersections of gender studies and literacies, see especially Margaret W. Ferguson, Dido's Daughters: Literacy, Gender, and Empire in Early Modern England and France (Chicago: The University of Chicago Press, 2003), pp. 1-178. See, in eighteenth- and nineteenth-century contexts respectively, J. Paul Hunter, "Sleeping Beauties: Are Historical Aesthetics Worth Recovering?" Eighteenth-Century Studies 34.1 (2000), pp. 1-20, and Virginia Jackson, Dickinson's Misery: A Theory of Lyric Reading (Princeton: Princeton University Press, 2005).

8. See Nancy Vickers, "Diana Described: Scattered Woman and Scattered Rhyme," Critical Inquiry 8 (1981), pp. 265-80, and John Freccero, “The Fig Tree and the 
Laurel: Petrarch's Poetics," in Literary Theory/Renaissance Texts, ed. Patricia Parker and David Quint (Baltimore: The Johns Hopkins University Press, 1986), pp. 20-32.

9. On the need to acknowledge a wider vision of Petrarchan influence and its relationship to the sonnet, see Diana E. Henderson, "Female Power and the Devaluation of Renaissance Love Lyrics," in Dwelling in Possibility: Women Poets and Critics on Poetry, ed. Yopie Prins and Maeera Shreiber (Ithaca: Cornell University Press, 1997), pp. 38-59 and Passion Made Public (Urbana: Illinois University Press, 1995), pp. 1-32. See also Wendy Wall, The Imprint of Gender: Authorship and Publication in the English Renaissance (Ithaca: Cornell University Press, 1993); Mary B. Moore, Desiring Voices: Women Sonneteers and Petrarchism (Carbondale: Southern Illinois University Press, 2000); and Distiller. On Ann Lok's (or Lock's or Locke's) sonnets - truly the first English sonnet sequence, prior to Thomas Watson's - as challenging Freccero's generalization, see Rosalind Smith, “'In a mirrour clere': Protestantism and Politics in Anne Lok's Miserere mei Deus," in Clarke and Clarke, eds., pp. 41-52 especially, as well as Margaret Hannay, “'Unlock my lipps': the Miserere mei Deus of Anne Vaughan Lok and Mary Sidney Herbert, Countess of Pembroke," Sixteenth-Century Essays \& Studies 23.1 (1993), pp. 19-36.

10. Cited from the introduction to Pamela Joseph Benson and Victoria Kirkham, eds., Strong Voices, Weak History: Early Women Writers and Canons in England, France, and Italy (Ann Arbor: University of Michigan Press, 2005) p. 4; see, in that volume, Virginia Cox, "Women Writers and the Canon in Sixteenth-Century Italy: The Case of Vittoria Colonna," pp. 14-31.

11. See Benson and Kirkham, pp. 5-8, which also discusses the complexity of manuscript circulation in determining English reception history and cross-cultural influence; while they emphasize the invisibility of English women's writing precisely because it occurred in genres other than the public and Petrarchan, conversely we may have missed the intersections between discourses by maintaining an overly constrained definition of those latter categories. For more on women's manuscript poetry, see Jill Seal Millman and Gillian Wright, eds., Early Modern Women's Manuscript Poetry (Manchester: University of Manchester Press, 2005).

12. See Pamela Joseph Benson, “The Stigma of Italy Undone: Aemilia Lanyer's Canonization of Lady Mary Sidney," in Benson and Kirkham, pp. 146-75.

13. See Victoria Kirkham, "Sappho on the Arno: The Brief Fame of Laura Battiferra," in Benson and Kirkham, pp. 176-98. 
14. Cary's Tragedy of Mariam had earlier demonstrated her comfort with the alternating rhymes and couplets that form the English sonnet's component parts.

15. "Written in Lady Elizabeth Cary's hand on a leaf in the Beinecke Library copy of The Reply of the Most Illustrious Cardinall of Perron. Douay: Martin Bogart, 1630. Rpt. in Arlene Iris Shapiro, 'Elizabeth Cary: Her Life, Letters and Art', Diss. State University of New York at Stony Brook, 1984." Cited from Kissing the Rod: An Anthology of Seventeenth-Century Women's Verse, ed. Germaine Greer et al. (New York: Farrar Straus Giroux, 1988), pp. 59-60.

16. See Melville’s Spenserian sonnet addressed to "My dear Brother" John Welsch, the initial offering in the Kissing the Rod anthology, Greer et al., p. 33. On women's reading of poetry, including sonnets, from Askew through Wroth, see Edith Snook, Women, Reading, and the Cultural Politics of Early Modern England (Burlington: Ashgate, 2005).

17. Kate Chedgzoy, Reading Women's Writing in the Atlantic World: Memory, Place and History, 1550-1700 (Cambridge: Cambridge University Press, 2007), p. 104; see also pp. 99-103.

18. Diana Primrose, A Chaine of Pearles, or a Memoriall of Q. Elizabeth, cited from Brown Women Writers Online, accessed April 2, 2010 via the Folger Shakespeare Library's Hamnet website, http://textbase.wwp.brown.edu/WWO/php/rAll.php/ rAll.php?doc=primrose. chaine.html\&num $=00272$.

19. Primrose does include Chastity and Religion, I would note - two more familiar female virtues. See Lisa Gim, “'Faire Eliza’s Chaine’: Two Female Writers' Literary Links to Queen Elizabeth I," in Maids and Mistresses, Cousins and Queens: Women's Alliances in Early Modern England, ed. Susan Frye and Karen Robertson (New York: Oxford University Press, 1999), pp. 183-98.

20. J. William Hebel and Hoyt H. Hudson, eds., Poetry of the English Renaissance 1509-1660 (New York: Crofts, 1940), pp. 411-13. Conversely, many of the poems we now regard as standard sonnets did circulate with musical settings.

21. For example, the following poem in Folger Library V.b.198 is announced as a

\section{Sonnett}

Beauty, Honor, yeouth, and fortune

I importune

None of yow to be my friend

Theise Gambols end.

And I have gaynd a Rosy bed. 
Uppon your head

Trod out of thornes and cruell Cares

And now your wares

Semes noisome trumpery to my thoughts

Things good for noughts

O happy state that dying lives

And reason gives

A just accompt of her disdaining

By her lost Gayning:

[fol. 9r] Cited from Millman and Wright, p. 61.

22. Lady Anne Southwell, Folger MS V.b.198, Fol. 17; cited from Louise Schleiner, Tudor and Stuart Women Writers (Bloomington: Indiana University Press, 1994), p. 122. Schleiner posits that the addressee may be the Countess of Londonderry.

23. Phillis Levin, ed., The Penguin Book of the Sonnet: 500 Years of a Classic Tradition in English (New York: Penguin, 2001), p. xxxviii.

24. See Schleiner, p. 121.

25. I am citing the phrasing in Greer et al. that surrounds the direct quotation of Hutchinson, pp. 215, 214.

26. Paul Oppenheimer, The Birth of the Modern Mind: Self, Consciousness, and the Invention of the Sonnet (Oxford and New York: Oxford University Press, 1989).

27. This appears within a searching discussion of lyric "Size and Structure." See Dubrow, The Challenges of Orpheus, p. 185.

28. Conflation of Bodleian manuscripts Eng. Misc. c. 116, f. 10 and Eng. Poet. E. 87, p. 120, and Rawlinson Poet. 173.f 2v. Cited and as abbreviated from Greer et al., pp. 8-9. The discussion there focuses on anonymity and the challenges of gendered attribution.

29. Cited from Hirsch and Boland, pp.101, 384.

30. Hirsch and Boland, p. 102.

31. See Millman and Wright, pp. 147-48.

32. Millman and Wright, p. 257.

33. At my 2010 RSA presentation, it was suggested by the husband of Professor Marianne Micros that the number 28 might be perceived as a "feminine" number, associated with the lunar calendar.

34. Greer et al. express "suspicion" that "Ephelia" might be a composite of male and female poets based in part upon the tone of "Maidenhead" (p. 279). The tricky issue of "voice" and gender, glossed over (understandably) in Nigel Smith's and 
numerous other primarily historicist works, is crucial here. "To one that asked me why I loved J. G." strikes me as continuing a form of gendered mockery familiar within the female Petrarchan tradition, even as it draws on Donnean rhetoric in its opening "Why do I love? go, ask the Glorious Sun / Why every day it round the world doth Run." Acknowledging

There is no Reason for our Love or Hate,

'Tis irresistible, as Death or Fate;

'Tis not his Face; I've sence enough to see

That is not good, though doated on by me:

Nor is't his Tongue, that has this Conquest won;

For that at least is equall'd by my own:

the speaker continues to critique the carriage, temper, and age of this "worthless Man" whom she nevertheless adores, concluding, "Sure 'tis Decreed in the dark Book of Fate, / That I shou'd Love, and he shou'd be ingrate" (cited from Greer et al., pp. 280-81). Mingling the wry humour of Shakespeare's Sonnet 130 with the bleaker moments of Wroth's Pamphilia accepting errant Amphilanthus's absence, this "voice" seems gendered in the way Virginia Woolf in A Room of One's Own imagined the sexes functioning for one another: revealing the blind spots, the shortcomings invisible given our training and presumptions (as well as expressing here the lyric self's suffering).

35. Arthur Clifford, Tixall Poetry: with notes and illustrations (Edinburgh: James Ballyntine, 1813). Available at http://books.google.com/books?id=a6U_AAAAY AAJ\&pg=PP11\&lpg=PP11\&dq=arthur+clifford+editor+poetry+edinburgh\&so urce=bl\&ots=RwSqe2QRth\&sig=vTgUkUWWgGxkhlNqhhjzVyZU90Q\&hl=en \&ei=EiZYTdv-GIa0lQeOtbn3Bw\&sa=X\&oi=book_result\&ct=result\&resnum=

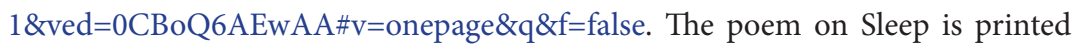
there only in abbreviated form (p. 294); the following text derives from a handout received at the initial 1994 Attending to Early Modern Women conference, in a seminar led by Nancy Dersofi, Daniel Javitch, Arthur Marotti, and Marilyn Williamson:

Sleep, the best ease of the most troubled minde,

Rest of our labours, nurse of human kinde,

Why so unkind to me; false joyes to frame,

When the most true partake too much of dreame? 
Waking, I see how extreame false they are, Which give us joy to purchase greater care.

Or wast thou meanst this way my hart to take By giving Joyes I can not find a wake. Where poverty hath dwelt (they are Like one All wayes in pleasure) custome makes it none; But those who half ether Life had consolation Must needs have greater sense of deprivation Then let me wake, or ever have such dreames, And not by contradiction know extreames.

("Women Poets in Manuscript and Print: Italy and England" seminar handout, p. 28)

Clifford omits lines 7-12, which, by contrast, linger on the poet's personal pain and specific "sense of deprivation."

36. Millman and Wright, p. 115.

37. On Elizabeth Major's Honey on the Rod: Or a comfortable Contemplation for one in Affliction (1656), see Elaine Hobby, Virtue of Necessity: English Women's Writing 1649-88 (Ann Arbor: University of Michigan Press, 1989). See also her observation: "Ephelia writes many songs with varied rhyme-schemes and line lengths, and her attention to the fine detail of the possibilities of patterning language is also suggested by the inclusion of four acrostic poems" (p. 147).

38. Cited in Early Modern Women Poets (1520-1700): An Anthology, ed. Jane Stevenson and Peter Davidson (Oxford: Oxford University Press, 2001), pp. 362-63.

39. Louis Zukofsky, "American Poetry 1920-1930," in Prepositions: the Collected Critical Essays of Louis Zukofsky (Berkeley: University of California Press, 1974), pp. 143-44. Jeff Hilson, ed., The Reality Street Book of Sonnets (Hastings, East Sussex: Reality Street, 2008), pp. 15-16.

40. Hilson, p. 15.

41. To add couplets need not be an exercise in canon reformation understood narrowly (taking into account the recognitions by John Guillory, Elizabeth Hanson, and others regarding alternative ways of reading early modern texts), especially if the range of potential candidates leads to a rotation of sonnets - rather than uniform selection of just the same few poems across anthologies and scholarship.

42. For more on Henry King's poetic transformation as a result of historical upheavals, see Diana E. Henderson, “King and No King: 'The Exequy' as an Antebellum 
Poem," in The Wit to Know: Essays on English Renaissance Literature for Edward Tayler, ed. Eugene D. Hill and William Kerrigan (Fairfield, CT: George Herbert Journal Special Studies and Monographs, 2000), pp. 57-75. Simultaneously published as a special issue of The George Herbert Journal 22, 1\& 2 (1998/99), pp. $57-75$.

43. Anne King (Dutton Howe), cited from Greer et al., p. 181.

44. Delarivier Manley, cited from Early Modern Women Poets, ed. Jane Stevenson and Peter Davidson (Oxford: Oxford University Press, 2001), p. 503.

45. For more on this generation being influenced by earlier female poets, see Carol Barash, English Women's Poetry, 1649-1714: Politics, Community, and Linguistic Authority (Oxford: Clarendon Press, 1996), and especially her recognition that "Women's poetry of this period has suffered a great deal from what I would call under-reading: the assumptions, first that these women were merely writing about their own experience; and, secondly, that their poetic speakers, literally and simplistically, reproduce that experience" (p. 20). 
